\title{
mELINTAS
}

33.1.2017 [1-13]

\section{GENDER IN RELIGIOUS ETHICS AND PRACTICES}

\author{
Ogbujah Columbus Institute of Foundation Studies (Faculty) \\ Rivers State University, Port Harcourt, Nigeria
}

\begin{abstract}
:
There is a somewhat symbiotic relationship between religion and culture: religious practices shape, and are shaped by the culture within which they thrive. When people in a given culture adopt a specific religion, their culture begins to assimilate only the ethos and practices that are acceptable within that religion; and when a particular religion arises within a given culture, its ethics and rituals are usually grounded on the tenets of that culture. Thus, having strong roots in patriarchal and androcentric cultures, Abrahamic religions cannot shy away from the encumbrances of flawed gender relationships. With the help of feminist studies, we have unearthed the insidious force of gender in the assignment of roles 'skewed' to favour men over women not only in politics and commerce but also in religious and social lives. The idea is not to take a knock at the spiritual values represented by these bodies, but to highlight the underlying influence of gender on the various ethics and practices of Judaism, Christianity and Islam.
\end{abstract}

Keywords:

gender $\bullet$ ethics $\bullet$ religious practices $\bullet$ patriarchy $\bullet$ roles

\section{Introduction}

Life, religion, and attainment of one's destiny are front-burner issues in every age and civilization. Now, and again, human beings are confronted with realities which critically challenge their resolves, and unsettle their long-held cherished traditions. For instance, in the ancient and medieval times, the belief in the existence of a creating and sustaining, all-powerful God was taken for granted. Human's plight was neither how 
to discountenance this reality, nor to jettison the form of His revelation or cult as espoused by his emissaries. Rather, man was enmeshed in the struggle to be counted favourably in the sight of deities.

At the age of enlightenment, perspectives began to shift; people began to question some realities which hitherto were taken for granted, including the existence of God. Beginning with the Cartesian 'methodic doubt', and expanded by the existentialism and phenomenology of Kierkegaard, Nietzsche, Sartre and Heidegger, there was a shift on emphasis from the object of metaphysical enquiry - God, to the subject of enquiry - man himself. Human became the center of activities and enquiry, and anything that did not gratify him was left in abeyance. Aided by tremendous growth in science and technology, this metaphysical revolt culminated in the denial and / or questioning of the existence of God, and the propriety of the various modes of worship and practice of religion.

In a lapidary of events, the modern times conditioned the intellectual and religious posture of the contemporary age. Even though religious issues remained sensitive, drawing aspersions for those who dared critiqued its modus operandi, they faced great challenge in postmodern world. Postmodernism engendered analytical intellectual culture which led to the formation of groups actively resistant to traditional religious beliefs. One of such groups - feminism - has gone at length to unearth the insidious force of gender in the assignment of roles 'skewed' to favour men over women not only in politics and commerce but also in religious and social lives. In this paper, we shall limit our efforts to examining the underlying influence of gender on the various ethics and practices of Abrahamic religions viz. Judaism, Christianity and Islam.

\section{The Concept and Meaning of Gender}

The issue of gender is something that has gained currency in the areas of philosophy, psychology, sociology, anthropology, literature, history and even law and medicine (Krijnen and van Bauwel, 2015). Its studies are devoted to gender identity and gendered representation as central categories of analysis. As I noted elsewhere, gender is the meaning that society attaches to being female or male - that is feelings, thoughts and behaviour that are defined as feminine or masculine (Ogbujah, 2012). 
When, for instance, Simone de Beauvoir $(1949,1989)$ espoused that "one is not born a woman, one becomes one", she must have intended the term - woman to be used in the sense of femaleness. Even though Garrett (1992) interpreted her as wanting the term gender to be used for the social and cultural constructions of masculinity and femininities and not to the state of being male or female in its entirety, some other theorists with psychoanalytic (Jacques Lacan) and feminist (Judith Butler) backgrounds have opposing views. For instance, Butler (2013) sees gender as 'performative'; something that produces a series of effects. For her, "we act and walk and speak and talk in ways that consolidate an impression of being a man or being a woman", and no identity exists behind the acts that allegedly 'express' gender. On the contrary, these acts create, rather than express, the deception of the stable gender identity. Butler argues that gender is contingent and open to interpretation and 'resignification', and challenged assumptions about the distinctions often made between sex and gender, according to which sex is biological while gender is culturally constructed. For her, both sex and gender are constructed.

In their view, West and Zimmerman (1977: 126) regard gender as "an emergent feature of social situations both as an outcome of and a rationale for various social arrangements, and as a means of legitimating one of the most fundamental divisions of society." In this sense, gender is understood as the degree to which an individual who is considered an actor is masculine or feminine, in light of societal expectations about what is appropriate for one's sex category. This can be evident in a variety of activities such as conversation, mannerisms, appearance, body language, etc., and the maintenance of its structure is largely dependent on social interaction.

Traditionally, gender is construed as means of distinguishing between biological sex and socialized aspects of femininity and masculinity (Mareak, Crawford and Popp, 2004). This idea seems to give it away as a more or less stable reality after its early acquisition in childhood. It is on the basis of this seeming stable structure that constructionist have latched their criticisms holding that gender is an activity of utilizing normative prescriptions and beliefs about sex categories based on situational variables (Fenstermaker and West, 2002). As an activity, it is fluid and 
dynamic, and could manifest in varying forms and degrees depending on a whole bunch of factors external to the referent. But to repudiate gender as foisting stable identity on individuals is not something novel to the constructionist. In acknowledging that sex is a biological factor similar in all societies and cultures, while gender is a socio-cultural and historical construct that varies from culture to culture, and over time within a culture (Ogbujah, 2012), traditional concepts recognize that embedded in the idea of gender is the element of fluidity which is coterminous with any issue whose reality is linked to cultural vagaries. However, Butler's radical views seem to have found significance by engendering some kind of agitation to social norms that tend to foist identity on people. From hers has emerged much conversation on 'queer' and 'transgender' attractions.

In practice, it is counter-intuitive not to separate the processes of sex identification from gender signification. Notwithstanding sex reassignment procedures, sex has a biological determinant, while gender is socio-cultural and fluid. Sex alone does not create inequality. Inequality emerges from faulty socialization of individuals to hold attitudes and values regarding what is appropriate or otherwise pertaining men's or women's activities, and how they should be appreciated. Feminism has come to unfold much of the barriers that women and minorities face as being grounded in twisted socialization rather than on nature or revelation.

\section{Religious Ethics and Practices}

In general terms, ethics refers to a code of conduct that directs an individual or group relating to the rightness or wrongness of human action (Ogbujah, 2006). It is all about principles that engender 'the good life' - the ultimate quest of humans. Individuals in all ages have always sought for this 'good life' in the pursuit of their personal health, wealth and overall wellbeing. But this often leads to clangs and conflict of interests, which necessitate the establishment of rules of engagement. Ethics then is that code of conduct which enables individuals to lawfully direct their lives towards their varied ends (Ogbujah, 2006).

Religion, as relating to institutionalized system of attitudes, beliefs and practices; or the service and worship of God/supernatural (MerriamWebster), necessarily demands a code of conduct. Every religion has ethical components derived from divine revelation and long-standing 
traditions. The type of ethics that grounds practices in specific religions is dependent on these two specific sources - revelation and tradition, which are not uniform for all creeds. This explains why, in reality, different religions can have conflicting ethical practices. Religious ethics are thus, the moral principles that guide religions and set the standard for what is good or bad, acceptable or unacceptable behaviour, which include norms and guidelines regarding worship, rituals and leadership.

The possibility of diverse religions engaging in conflicting ethical practices seems to challenge the old exercise of identifying 'general ethics' with 'religion', and the assertion that religion is necessary to live ethically. Philosophical ethics, for instance, while it may have derived a lot from religious principles, is structured on human reasoning and does not need religion for its applicability. Neo-liberal ideologies such as 'Secular Humanism' and 'Utilitarianism' have amply demonstrated this. While 'science of morality' is based on human reasoning and the rational justification of ideas, religious ethics have a supernatural foundation and could sometimes be twisted to serve the interest of 'ecclesial hierarchies.' Since, as is obvious, different religions sometimes practice conflicting ethics, it would be absurd not to seek for the basis of ethics with a universal application from somewhere else other than religion. Hence, Blackburn's (2001) acknowledgment of those who claim that people can only flourish under the umbrella of a strong social order cemented by common adherence to a particular religious tradition, needs to be properly reexamined.

As relating to the worship and service of a particular God, religion is a unifying factor which can aid social order and growth. But as it deals with ideas that transcend everyday experience, neither common sense nor scientific expertise is sufficient enough to validate religious ethics. Religious ethics rather is anchored on faith on the revealed 'truth' codified in 'Sacred Books', and on the interpretations of the ecclesial hierarchy. Such a test of validity, coupled with apparent diminution of the role of women in worship and governance, has attracted a flurry of criticisms especially in postmodern world. Feminist theorists acknowledge, as other experts do, that religion is central to virtually every culture on earth. What they are greatly perturbed about is how religious ethics and practices have, over the centuries, consigned the role of women to the background. For them, it 
does seem that the 'hallowed chambers' of religion are not impervious to patriarchal gender bias.

\section{Gender Pattern in Religious Ethics and Practices}

A review of available statistical data provided by scholars (Beit-Hallahmi and Argyle, 1997; Pew Research Center, 2014) shows that women are generally more religious than men, especially among Christians. This is in spite of the fact that virtually all the charismatic religious leaders like Abraham, Moses, Jesus, Mohammad, Siddhartha Gautama, are males. In her survey of the population of 192 counties between 2008 and 2015, the Pew Research Center, using a multi-layer indicator because of widely differing societies and faiths, confirmed that globally, women are more devout than men by several standard measures of religious commitment, like religious affiliation, frequency of worship service attendance, frequency of prayer, and whether religion plays an important role in a person's life.

Over the years, religious scholars have advanced reasons for this religious gender gap, ranging from biology, psychology, genetics, family upbringing, to social status; from workforce participation to a lack of "existential security" felt by many women. In sum, these could be reduced to the influences of 'nature' and 'nurture'. In their 1997 research, BeitHallahmi and Argyle admitted of three basic causes for this occurrence namely, a) women feel emotions at greater heights than men do, and thus frequently turn to religion during experiences of high emotion like gratitude or guilt; b) female socialization is more likely to align with values commonly found in religion, than male socialization; and c) females are more likely than males to identify with religion as a natural consequence of societal structures. The less the women were engaged in labour force, the more they reported the importance of religion and daily prayer.

In spite of the aforementioned stunning discoveries, patriarchy still remains a prevailing feature in religious organizations, and the dominant gender within the ranks of the faithful, has remained at the fringes in terms of governance, education and worship. There seems to be a scholarly consensus that deities in both monotheism and polytheism are gendered. In Christian monotheism, for instance, Jesus Christ - the Second Person of the Trinity, is believed to be the only one to have incarnated into a male. The other two divine persons - Father and Holy Spirit - are 
acknowledged as having masculine gender rather than male sex. Thus, Christian monotheism is unmistakably revealed as a religion with male or masculine deity. Judaism and Islam do not admit of a Trinitarian God, and as such, are less concerned with these subtleties. In their sacred books, adherents interpret masculine pronoun for deities only in generic sense.

Furthermore, the influence of gender is radiant in creation myths of many religions. In the Christian Scriptures, we read in Genesis 1:27 "And God created the man in his image. In the image of God he created him. Male and female he created them." While this passage seems to present a gender-inclusive account of creation, Boyarin (1998) pointed out that the use of the singular term - 'human race' (Adam in Hebrew) in the text should be viewed as an ideal who can be distinguished as both male and female. Meaning, that in the creation of Adam (human race), there is already subsumed the idea of Eve. Eve was to be understood as already contained in Adam. This subordination is then brought out more vividly in the second creation account (ref. Gen. 2:27) where the first woman (Eve) is created from the rib of the first man (Adam) as a companion and helper (Boyarin, 1998). Both Jewish and Christian authorities sometimes reference this account in defense of patriarchy. On the other hand, the Quran gave no explicit detail regarding the origin of Adam and Hawwah (Eve), albeit an Islamic scholar - Yasir Qadhi (2014) claims that they were created through a miracle by Allah.

Perhaps, in no greater area than in leadership roles, is the influence of gender on religious ethics and practices felt. A dispassionate scrutiny of Abrahamic religions in focus - Judaism, Christianity and Islam, - reveals that leadership positions, for the most part, are restricted to males. The founders and key figures of these religions - Abraham, Moses, David, Elijah, etc., in Judaism; John the Baptist, Jesus Christ and his Apostles, and Paul, in Christianity; Mohammad, and his successors Abu Bakr, Umar, Uthmanibn Affan, Ali ibn Abi Talib and the Twelve Imams, in Islam were all men. These religions developed theologies within patriarchal cultures that restricted leadership roles in worship and administration to males. In Christendom, for instance, the formation stage was followed by a millennium of theologians known as the Church Fathers. No one hardly writes about the Church Mothers, because they are non-existent; except in the case of female Saints in the Catholic church, no literature espouses, 
on equal footings, the heroic works of women within that period, in the growth of these religions. No! They were not as prolific and ingenious as their male counterparts. Thanks to the hegemonic influence of patriarchy, only men were to be enlightened; thanks to the same influence, women could not make history and contribute to culture. Mary Wollstonecraft (1982: 10) once queried why a woman would not stop the progress of knowledge and virtue "if she be not prepared by education to become the companion of man." She simply could not come to terms with why women's potentials were stunted by a (religious) culture that viewed them as merely emotional and less human.

Obviously, the absence of women among the "pillars" that designed the foundation and organizational structure of these religious bodies is a 'slide' that echoes the wider level of subjugation and attenuation that women faced in the world. Having no presence among the crafters of the administrative machinery of these bodies, it was expected that women would play subservient roles in these religions. In her more than two thousand years of history, the Catholic Church, for instance, has not recorded a female Pope. Women are not called to 'higher' ministries, and even ordained ministers are presently barred from marital relationships. From plain analytical and critical perspectives, this doesn't make sense, except the theological ramifications enunciated by the hierarchy are properly factored in. The controversy surrounding the ordination of women in some Christian denominations is a feature of the $19^{\text {th }}$ century and beyond. Without the scatting pressure from feminist and liberal theories, it was inconceivable for women to lead congregations at worship liturgies.

Among the traditional Jews, women are not only denied opportunities within the hierarchy, but are often treated in a condescending manner. As 'objects of distraction', women are prevented from the sights of men in prayer with a wall or curtain known as mechitza. The ordination of the first two Orthodox women in Israel on June 10, 2015 notwithstanding, women have not fared well in leadership roles in Judaism. In Islam, it was not possible for a woman to conceive of being an Imam or religious leader given the subservient role placed on them by the Quran $(4: 34 ; 2: 228 ; 33: 53 ; 33: 59)$. As in Judaism, women are seen as 'objects of 
seduction' and are often restricted from interacting with men in prayer and worship liturgies. Even when they could not find direct Quranic backing, Islamic leaders, among other sundry issues, passed fatwas which prohibit women from wearing perfume, nail polish or anything adjudged to be capable of causing 'sexual distress' to men. It is typically a men's show, and women are constrained to wearing hijab and praying behind men or in separate rooms.

The recent moves by some Islamic communities outside the Middle East to appoint female Imams is a ruse, otherwise, their ministries would not have been restricted to leading women in prayers and charitable works. It is a skillful ploy within the grand design to minimize the overall interaction of men and women in Islamic life and worship. When on the $25^{\text {th }}$ of September 2011, King Abdullar announced that women in Saudi Arabia were to be given the right to vote and run in elections, many people were stunned that such a restriction still exists in this $21^{\text {st }}$ century. Up till now, in the name of religion, women are barred, in some Islamic nations, from driving cars or moving around without the 'guardianship' of a male, or simply from going to some public spaces like a football stadium to enjoy soccer competition.

This shows that social life is no less spared of gender conundrum. Guidelines pertaining to marriage, dress code and deference even in the face of provocations, are all skewed in favour of males. In Islam, a man could marry a Muslim, Jew or Christian woman; but a woman is not permitted to marry except a Muslim man. Her marriage could be terminated simply by the triple pronouncement of "I divorce you" by the husband. In sum, the traditional roles of women in Abrahamic religions are as wives, mothers and keepers of the household: roles which denied them equal opportunities for enlightenment, and paved way for their attendant social and economic woes.

\section{Conclusion}

Religious ethics and practices can influence the attitude and behaviour of entire people within societies. Religious practices shape, and are shaped by the culture around them. When people in a given culture lean heavily on a particular religion, their culture begins to assimilate only the ethos and practices that are acceptable within that religion. This is 
evidenced in the spread of Christianity in the early Roman Empire; Islam in the regions of Arabia and North Africa; and Judaism in Israel. The cultures of these various societies today are deeply laced with guiding ethics of the grounding respective religions.

Human progress and critical reasoning have sought to reduce religious influence on culture by tilting towards another extreme 'secularism'- an orchestrated disdain for religious practices, especially in Western hemisphere. Yet, they have not generated enough bite to burden the consciences of those whose grip on power is as a result of skewed religious gender disparity. Ironically, modern beneficiaries of this historically flawed relationship find it convenient to frequently repudiate religion, while at the same time clinging to the pecks of their offices.

Christianity, Judaism, and Islam, in their origin and history, were typically androcentric and patriarchal: their founders were males; their texts and rituals are, for the most part, focused on men, with women at the fringes; their leaders were and still are men taken to be strong, assertive and divinely inspired. All of these make feminist writers like Allison Kilkenny (2017) conclude that in religion, men are superior to women, and anyone who believes men and women are inherently equals cannot claim to believe in the fundamental beliefs of any religion. Though an extreme view, what feminists in general find difficult to comprehend are teachings as are found in 1 Cor. 11:7-9 which asserts that man "is the image of God and reflects God's glory; but woman is the reflection of man's glory,... nor was man created for the sake of woman, but woman for the sake of man." Though St. Paul immediately tried to douse the tension elicited by this gender attenuating passage by noting that men and women were equally made by God (1Cor. 11:11-12), the already provoked view of male superiority and female inferiority has pervaded in some religious circles till date.

The women who claimed rights to ordination in the Catholic Church felt that theirs is "a renewal movement" within the church which aims at "full equality for all within" as "a matter of justice and faithfulness to the gospel" (Meehan, 2017). Although excommunicated by Pope Benedict XVI in 2007, the group's clamour for equality of treatment seems to have caught the attention of some prominent members of church hierarchy. In August 21, 2017, Cardinal Reinhard Marx was cited in The Irish Times 
as saying that the fact that only men can be ordained Catholic Priests was "certainly not helping the church come across as a pioneer of equal rights." More recently (Nov. 16, 2017), Diarmuld Martin - Archbishop of Dublin - lamented that the low standing of women in the Catholic Church is the most significant reason for the feeling of alienation towards it in Ireland today.

In all, the influence of gender on Abrahamic religious ethics and practices cannot be overstated. With the rise of feminism and critical theories in the $19^{\text {th }}$ century, a lot has been done to reduce the gap, especially within Christendom and Christian oriented cultures. But more still needs to be done. Caution, however, must be applied in the process, so that no group would use gender equality as a subterfuge for advancing 'neocolonial' tendencies of "gender ideology."

\section{References:}

Argyle, M. \& Beit-Hallahmi, B. The Psychology of Religious Behaviour, Belief and Experience. New York: Routledge, 1997.

BBC NEWS. 25 September 2011. "Women in Saudi Arabia to vote and run in elections." Retrieved on 19/11/2017 from: www.bbc.com/ news/world-us-canada-15052030

Beauvoir, S. The Second Sex. Trans., \& edited by H. M. Parshley. New York: Alfred A. Knof, Inc., 1952.

Boyarin, D. "Gender." in M. C. Taylor (Ed.). Critical Terms for Religious Studies. Chicago: University of Chicago Press, 1998.

Butler, J. Gender Trouble: Feminism and the Subversion of Identity. New York: Routledge, 1990. ,"Critical Theory”. Retrieved on18/11/2017 from:

https:/ / my.vanderbilt.edu/criticaltheoryfall13/2013/judith-butler-ongender-as-performed-or-performative/

Fenstermaker, S. and West, C. Doing Gender Doing Difference: Inequality, Power and Institutional Change. New York: Routledge, 2002.

Kilkenny, A. (2011). “God Hates Women.” Retrieved on 20/11/2017 from: https://m.huffpost.com/us/entry/56984

Krijnen, T. and van Bauwel, S. Gender and Media: Representing, Producing. New York: Routledge, 2015. 
Marecek, J., Crawford, M. and Popp, D. "On the Construction of Gender, Sex and Sexualities," in A. H. Eagly, A. E. Beall, and R. J. Sternberg (eds.). The Psychology of Gender. New York: Guilford Press, 2004.

Martin, D., as cited by P. MaGarry. (Nov. 16, 2017). "Catholic Church's stance on women alienates people, archbishop says", in THE IRISH TIMES. Retrieved on 20/11/2017 from: https://www. irishtimes.com/news/social-affairs/religion-and-beliefs/catholicchurch-s-stance-on-women-alienates-people-archbishop-says1.3294859 ? mode $=$ amp

Meehan, B. M. (Aug. 15, 2017). Cited by P. MaGarry. "Catholic woman bishop on Irish vocations recruitment drive," in THE IRISH TIMES. Retrieved on 20/11/2017 from: https://www.irishtimes. $\mathrm{com} /$ news / social-affairs/religion-and-beliefs/catholic-womanbishop-on-irish-vocation-recruitment-drive-1.3186561? mode $=$ amp Qadhi, Y. (13 September 2014). Cited by E. Lim. "Muslim Scholar explains relationship between evolution and the Quran." The Daily Pennsylvanian. Retrieved on 16/11/2017 from: http://www.thedp. com/articles/2014/msa-modern-theory-of-evolution-presentation

"QuranicPath." Retrieved on 19/11/2017 from: www.quranicpath.com/ misconceptions/perfume.html

Reinhard, M., as cited by P. MaGarry. (Aug. 21, 2017). "Catholic church's idea of gender equality may be too little, too late," in THE IRISH TIMES. Retrieved on 20/11/2017 from: https://www. irishtimes.com/news/social-affairs/religion-and-beliefs/catholicchurch-s-idea-of-gender-equality-may-be-too-little-too-late1.3192397? mode $=$ amp

Simon, B. Ethics: A Very Short Introduction. Oxford: Oxford University Press, 2001.

The New Jerusalem Bible. (Standard Edition, 1985). London: Darton, Longman \& Todd Ltd.

The Pew Research Center. (2014). Religious Landscape Study. Retrieved on 20/11/2017 from: http://www.pewresearch.org/topics/ search/?query $=$ The $\% 20$ religiouos $\% 20$ landscape $\% 20$ study 
West, C. and Zimmerman, D. "Doing Gender," in Gender and Society 1 (2), 1987: 125-151.

Wollstonecraft, M. A Vindication of the Rights of Women. London: Richard Clay, 1982. 